\title{
Narrative Form and Mahler's Musical Thinking
}

\author{
Robert Samuels \\ The Open University \\ Email: r.samuels@open.ac.uk
}

\begin{abstract}
The close relationship between music and other art forms is a well-established feature of fin-de-siècle Vienna. Interdisciplinary study since the 1970s, of the relationship between literature and music, reflects among other things a recovery of nineteenth-century concerns. This article equates Mahler's development of symphonic form with a development of narrative form within his works, by linking three phases of his symphonic output with his literary interests. The first phase links the early symphonies with the early nineteenth-century author Jean Paul. His novel Titan provides the subtitle of Mahler's First Symphony, and correspondences can be discerned between the character of Albano, the hero of the novel, and Mahler at this stage of his career (1888). The opening of the Finale of the symphony shows narratological similarity to the opening of the final volume of the novel. The second phase links the middle-period instrumental symphonies with Dostoevsky, who became Mahler's greatest literary and moral hero. The Fifth, Sixth and Seventh Symphonies exhibit narrative structures different from those of the earlier symphonies; rather than ending with indivdualistic triumph, after the manner of Jean Paul, they pose the Dostoevskian question of whether some sort of redemption of their material is possible. The third phase links the late works with Mahler's contemporaries Robert Musil and Marcel Proust. In this context, the ending of Mahler's Ninth Symphony can be seen as a adaptation of musical narrativity analogous to the Modernist extension of the lengthy novels of these two authors.
\end{abstract}

Apparently trivial anecdotes of musical history sometimes sum up moments of far greater cultural significance than at first seems the case. The evening that Mahler spent talking and drinking with Schoenberg, Berg and Webern, among others, is just such an example. It took place some time between 1907 and 1910, at the 'zum Schutzengel' restaurant in the Döbling district of Vienna. ${ }^{1}$ Mahler had assembled 'young people' of the Viennese musical scene with the help of Schoenberg and Zemlinsky, and held forth at length, particularly on the subject of his favourite author, a writer whom he had loved since his adolescence. On becoming increasingly frustrated at the evident lack of acquaintance with the works he was discussing, Mahler eventually turned to Schoenberg in exasperation, and asked: 'Have your pupils read Dostoevsky? That is more important than counterpoint!' What one imagines to have been an embarrassed silence was, according to Berg, timidly broken by Webern, who ventured the apologetic, 'Please, we've had Strindberg...'.

1 Accounts of this evening exist from Alma Mahler, Alban Berg, Richard Specht and Paul Stefan. Alma gives the earliest date, 1907, shortly before Mahler's departure for America; her memories are of a considerably more raucous and lively occasion than those of the young musicians present. They all place it during the spring of one of the following years. The various accounts are well summarised in Norman Lebrecht, Mahler Remembered (London: Faber \& Faber, 1987): 219-22. 
Apart from the appealing vividness of this exchange, coloured variously by reverence, respect and nostalgia in the differing recollections of it, there are various ways in which it emblematises intellectual and creative life of early twentiethcentury Vienna. That music and prose, and indeed poetry, drama, painting and philosophy are all of a piece in fin-de-siècle culture is hardly a new contention. Since the 1970s in particular, studies of their inter-relationships have become seminal for a generation of scholars. ${ }^{2}$ This in part reflects the fashion in scholarship of the last 40 years for inter-disciplinary topics; but it is also a recovery of an aspect of the nineteenth-century intellectual climate which had been largely effaced by the specialisation and positivism of the mid twentieth century. The fact that there is relatively little scholarly writing that compares Mahler's musical thought with the practice of contemporary or earlier literary authors, is as much as anything an indication of how far the concerns of music analysis have been determined by two other Viennese thinkers of the fin-de-siècle, Schoenberg and Schenker. This has begun to change more recently, as the influence of literary theory and narratology has been felt in music analysis as in the other humanities disciplines. ${ }^{3}$

To look within literary texts for analogies with Mahler's musical texts, then, is both justifiable historically and in line with much of our own contemporary theoretical practice. The suggestion that there are specific narrative tropes common to novels and Mahler's symphonies has suggested itself to several scholars. Anthony Newcomb, one of the pioneers of this sort of inquiry, has explored parallels which he hears between the Ninth Symphony and the Bildungsroman, ${ }^{4}$ and the present author has not been immune to the seductive force of such speculation. ${ }^{5}$ What this essay aims to do, however, is to trace a developing history within Mahler's engagement with different models of narrative. Studies such as Newcomb's have sought to place Mahler's works alongside a generic formal model, such as the Bildungsroman, which can be deemed to be characteristic of the nineteenth century as a whole; the assumption is that this is such a typical and well-used method by which a narrative articulates and interprets lived experience, that its appearance as a point of reference for symphonic form is an inevitable outcome of the music's participation in the artistic life of its time. What is at stake is a matter of archetypes, rather than the influence of specific writers or works upon the individual composer. While I would accept most of these assumptions, I think it would nevertheless be wrong to assume that narrative archetypes simply exist as a ready-made stock for the nineteenth-century artist (writer or composer) to draw upon, any more than musical forms function in this way. Mahler's approach to musical form develops and changes throughout his composing career, and indeed contributes decisively to the use of the forms he employs. This is particularly true regarding the twentieth-century use of symphonic form. The intention of this essay is to sketch briefly this development in Mahler's thinking, in terms of a changing relationship to narrative as an organising force within musical form.

2 See in particular Allan Janik, and Stephen Toulmin, Wittgenstein's Vienna (New York: Simon and Schuster, 1973), and Carl E. Schorske, Fin-de-siècle Vienna: Politics and culture (Cambridge: Cambridge University Press, 1981).

3 See for instance the series Word and Music Studies, ed. Walter Bernhart, Werner Wolf and others (Amsterdam: Rodopi).

4 Anthony Newcomb, 'Narrative archetypes and Mahler's Ninth Symphony', in Music and Text: Critical inquiries, ed. Peter Scher (Cambridge: Cambridge University Press, 1992): 118-36.

5 Robert Samuels, Mahler's Sixth Symphony: A study in musical semiotics (Cambridge: Cambridge University Press, 1995). 
At this point it is worth defining a little more closely what is meant by a 'narrative' description of musical form. What is at stake is more than simply an alternative method of analytical interpretation in the sense of a technique to be applied. To think of complex structures in music as the outworking of an impulse to narrate is, as I have argued, consonant with the environment that produced the works. Equally, not every sort of musical form can profitably be described in this way. So, what are the features that might indicate a narratological impulse on the part of the composer? For one thing, such an analysis is founded on the observation that meaning in the music arises not out of repetition of material, but out of its significant transformation. If a story is being told, then this implies change, action, event; the final state cannot be identical with the opening. This is precisely the observation that leads Theodor Adorno to entitle two of the chapters of his monograph on Mahler 'Characters' and 'Novel' respectively. ${ }^{6}$ But while Adorno makes acute observations concerning the consequences of the typically Mahlerian techniques of constant variation of themes and manipulation of traditional form, he is not concerned to draw many specific parallels between individual works of literature and Mahler's works. His main concern is to demonstrate what he terms Mahler's 'nominalism' of form, where a stultifying reliance on inherited models is ceaselessly avoided through the inventiveness of the handling of materials. The claim of the present essay is that this observation can be broadened through looking at different stages of Mahler's formal thinking.

I am going to discuss three distinct phases of Mahler's creative output, roughly corresponding to well-established divisions of his symphonic æuvre. These phases not only reflect observable changes in his compositional techniques, they also, to my mind, reflect changes of emphasis in his literary enthusiasms.

\section{The devotee of Jean Paul: the First Symphony}

The story of Mahler's engagement with narrative form in the symphonies begins with the subtitle of the First Symphony, Titan. This names the novel by Jean Paul as the point of reference for the young Mahler's first attempt to sustain the span of symphonic form. The exact significance of this 'point of reference', however, has been a subject of debate. Indeed, one of the most sensitive of Mahler's post-war biographers, Kurt Blaukopf, could not countenance any connection at all:

Mahler knew and loved the writings of Jean Paul, but anyone who has ever read any of the latter's work must conclude that there is no trace of his mannered style in Mahler's symphony. ${ }^{7}$

Blaukopf goes so far as to suggest that the title Titan, which certainly had Mahler's acquiescence, even if it was not published at the symphony's premiere, ${ }^{8}$ must refer in a much less specific manner to an ideal of 'Titanism', in a gesture

6 Theodor W. Adorno, Mahler: Ein musikalische Physiognomik (Frankfurt: Suhrkamp, 1960), trans. Edmund Jephcott, as Mahler: A musical physiognomy (Chicago: University of Chicago Press, 1992).

7 Kurt Blaukopf, Mahler, trans. Inge Goodwin (London: Allen Lane, 1973): 76.

8 The work was premiered in Budapest in November 1889. The title Titan was published, along with a programmatic description of the whole work, for the second performance, in Hamburg in 1893. Both these performances included as the second movement the later discarded Andante entitled Blumine. 
analogous to the title Eroica in Beethoven. ${ }^{9}$ That this is quite incorrect, is shown by the programmatic description of the symphony, prepared by Mahler with his friend Ferdinand Pfohl and published in the programme for the second performance. The title is given as 'Titan, a tone poem in symphony form: "From the days of youth", Flower-, Fruit- and Thorn-pieces', which refers to two of Jean Paul's novels (the full title of the novel Siebenkäs describes the book as 'Flower-, Fruit-, and Thorn-pieces'). ${ }^{10}$ Blaukopf's complete bafflement, in placing the novel Titan alongside Mahler's symphony, is indicative both of the gap between nineteenth-century and twentieth-century conceptions of the 'purity' of the symphony as a communicative art form, and of the fate of Jean Paul as an author.

Johann Paul Friedrich Richter (1763-1825) can accurately be described as one of the most famous and least read authors of German Romanticism. He adopted the pen-name 'Jean Paul' in homage, partly, to Rousseau; an indication both of the international context and the philosophical seriousness which he regarded as proper to his work. He was the author of works of aesthetics and educational theory, and edited the notebooks of Leonardo da Vinci; but his fame rests on his novels. He cited Sterne and Richardson as principal influences, and his writing is marked by extraordinary density of plot and descriptive detail. In particular, he consistently uses the motif of the Doppelgänger: characters are accompanied by their doubles, who may have similar names, or even exchange names with them, so that the potential confusion for the reader is immense. Jean Paul's style is also marked, however, by verbal brilliance, wit and humour, which attempts to draw the reader into an enveloping, absorbing, yet endlessly de-centred and quirky narrative universe. In the preface to Siebenkäs he jokes that he respects the Aristotelian principle that his book may be read in a single day, but he has in mind the six-month day of the frozen North.

The combination of intellectual seriousness, pervasive humour, and fascination with unstable, shifting identity explains immediately the appeal Jean Paul had for the composer most notable for his devotion to him, Robert Schumann. Schumann's famous epithet for Schubert's Ninth Symphony, that it is of 'heavenly length', is followed in the next sentence of his article by a comparison of it with 'a fourvolume novel by Jean Paul'. ${ }^{11}$ Mahler's own admiration for Jean Paul may have arisen independently (as did that of Brahms, for instance), but can only have been confirmed and strengthened by his love of Schumann's music and writings.

What, though, is the legacy of Titan within Mahler's First Symphony? This is a complex issue, which has been recently addressed by more than one scholar, although studies have tended to emphasise the heterogeneity of intertextual references in Mahler's symphony - something which, not surprisingly, is found to be as true of his glances towards literature or visual art as it is of his allusions to musical influences and forebears. ${ }^{12}$ The role played by Jean Paul's works, in

9 Blaukopf, Mahler.

10 The whole programme is translated in Peter Franklin, The Life of Mahler (Cambridge: Cambridge University Press, 1997): 89-90.

11 Robert Schumann, On Music and Musicians, trans. Paul Rosenfeld (New York: Norton, 1946): 107-112. Schumann's article dates from 1840.

12 Herta Blaukopf, 'Jean Paul, die erste Symphonie und Dostojewski', in Gustav Mahler: Werk und Wirken: Neue Mahler-Forschung aus Anlass des vierzigjahrigen Bestehens der Internationalen Gustav Mahler Gesellschaft (Vienna: Vom Pasqualatihaus, 1996): 35-42; Federico Celestini, 'Literature as Déjà Vu? The Third Movement of Gustav Mahler's First Symphony', in Phrase and Subject: Studies in Literature and Music, ed. Delia da Sousa Correa (Oxford: Legenda, 2006). 
particular, remains a fascinating question. For present purposes, the issue at stake is the extent of the reflection of Jean Paul's narrative within the musical process.

Despite Kurt Blaukopf's dismissal of any connection between Mahler's musical style and Jean Paul's manner of writing, there are elements within Titan that suggest themselves immediately as things which must have resonated with the young, ambitious composer's own aspirations in the early 1880s, when the First Symphony was gestating. The central character in this immense novel (it is Jean Paul's longest) is Albano, son of the Prince of Hohenfließ, from whom he is separated immediately after his birth. The novel finally ends with Albano's accession to his father's title, following his eventual discovery of his true identity and the death of his elder brother. This basic Bildungsroman frame surrounds a narrative of incredible complexity. Much of the story concerns Albano's relationship with the character Roquairol, whom he first encounters as a model held up to him during his education, and whom he later meets and befriends when he moves to Pestitz, the capital of Hohenfließ (a location based on Leipzig). Roquairol is, typically of any Jean Paul narrative, Albano's Doppelgänger, able to imitate his voice and handwriting perfectly; he is also the villain of the story, who seduces both Albano's foster sister and, later, Albano's intended wife Linda. Roquairol and Linda are both, in fact, 'Titans' in the sense of the book's title. They behave immoderately, and end by 'finding their own hell' as Jean Paul described it in a letter. ${ }^{13}$ Their immoderation, however, forms a part of their characters as geniuses, cultivating energy and creativity 'for their own sake'. ${ }^{14}$ The philosophical premise of the novel is to attack the idea that this manner of being is praiseworthy, or even sustainable. Albano ultimately wins by 'coming close' to titanic stature, while yet harnessing his aims to practical and humanitarian purpose. This purpose is fulfilled in his eventual union with his beloved - not Linda now, but Idoine, the widow of Albano's brother, Crown Prince Luigi; inevitably, Idoine is another Doppelgänger, uncannily resembling Linda and loving Albano no less. The union is sealed in a final chapter illuminated by moonlight, with Luigi's funeral as its backdrop. The closing peroration celebrates universal brotherhood, and its language shows the longevity of Jean Paul's (and in particular, this book's) influence over Mahler, since it is strikingly similar to the close of Das Lied von der Erde, at the opposite end of his output to the First Symphony. Here is the final sentence of the novel:

"Look up to the fair heaven!" cried the sister to the lovers, in the ecstasy of her joy; "the rainbow of eternal peace blooms there, and the tempests are over, and the world is all so bright and green. Wake up, my brother and sister!"15

And here is Mahler's own transformation of Bethge's poetry at the end of 'Der Abschied':

The lovely earth blooms everywhere in spring and is made green once more! Everywhere and forever, forever the distance turns blue and bright!

Forever ... forever! $!^{16}$

13 The foregoing description is based on the summary of the novel in Timothy J. Casey, Jean Paul: A reader (Baltimore: Johns Hopkins University Press, 1992): 22-27.

ibid., p. 22.

15 Johann Paul Friedrich Richter ('Jean Paul'), Titan, 4 vols. (Berlin: Matzdorff, 1800-03). English edition: Titan: A romance, trans. C.T. Brooks (Boston: Ticknor and Fields, 1862): vol. 2, p. 521 (Chapter given as 'Thirty-fifth Jubilee, $146^{\text {th }}$ Cycle').

16 'Die liebe Erde allüberall blüht auf im Lenz und grünt aufs neu! allüberall und ewig, ewig blauen licht die Fernen, ewig, ewig ... ewig, ewig ... ewig, ewig ... ewig!' 
The irony of a springtime of peace blooming in the shadow of death is an image which clearly appealed to Mahler throughout his life, reaching its most sublime manifestation here in a (possibly unwitting) reminiscence of the close of the novel most central to his literary interests at the outset of his composing career.

One aspect of Jean Paul's novel, which perhaps illuminates Mahler's fascination with it at the period of writing the First Symphony, is also something that in some measure accounts for Jean Paul's loss of readership in the twentieth century. Much of the action in Titan is taken up with the fine detail of class distinction and constant political manoeuvring by the aristocracy of the fictitious German states that are finally to be unified at its close. Albano is educated and groomed entirely in order to gain access to this class, which he eventually discovers to be his true birthright. The proliferation of detail, made obscure by the complexities of the plot, adds up to a narrative which is unbelievable - in other words, in no way 'Realist'. One suspects that this accounts in no small measure for Kurt Blaukopf's irritation with Jean Paul's 'mannered style'. Indeed, it is one respect in which Jean Paul appears much more wedded to an eighteenthcentury novelistic tradition than those contemporaries whose novels have carried their readership more successfully to the present. Such diverse novelists as Jane Austen, Madame de Staël - even, arguably, Walter Scott - have more manifest preoccupation with the emergent story-telling methods of the nineteenth century. It is tempting, however, to draw a parallel between the fallible, yet ultimately triumphant Albano, and the assistant theatre director in Leipzig in 1888, also undergoing an education in the ways of the world, and also ultimately triumphant, both with his Symphony, and more immediately with his move to Budapest as sole Director of the Hungarian Royal Opera. Despite the avowed socialism of Mahler's youth, his belief in his own innate greatness, by comparison with those around him, coincides quite harmoniously with the discovery by Albano of his true high birth and political destiny. One can imagine Mahler's sympathy with Albano's exclamation, when all is revealed in a letter from his true mother: 'Why [...] did they oblige me to owe so many thanks to so many a proud, stern spirit for my mere - birthright?'17

All this does little more, however, than to establish some of the likely grounds of Mahler's admiration for Jean Paul, and for this novel in particular, at the period of composing the earliest symphonies. The question remains as to how far the musical substance of the symphonies, and the First Symphony in particular, should be understood in the light of the sort of narrative embodied in Jean Paul's work. There is not space here to make a thoroughgoing attempt at a narratological description of the Symphony; but it is worth considering one particular moment, the treatment of which demonstrates many of the issues discussed above. This is also a moment crucial to the overall form of any symphony, and it thus makes an ideal point of comparison with Mahler's later practice, when his conception of symphonic narrative modifies in distinct ways.

The moment in question is the opening of the Finale. The 'Finale problem' is a cliche of criticism of the symphony as a form; ${ }^{18}$ but there are several factors that inevitably make the opening of a final movement a point at which certain crucial characteristics of the composer's handling of overall form in the work will

17 Jean Paul, Titan, vol. 2, p. 499 ('Thirty-fifth Jubilee, $143^{\text {rd }}$ Cycle').

18 It is one of the problems with a cliché that its actual origins are not clear. The phrase is prominent, for example, in William Newman, The Sonata since Beethoven (Chapel Hill: University of North Carolina Press, 1969); but it has general currency. 
become evident. The phrase, 'the Finale problem' usually refers to the necessity of writing a concluding movement that provides an aesthetically satisfying completion of the work, without appearing 'lightweight' or redundant alongside the complex, often extended sonata form Allegro of the first movement. There is a tacit assumption here that the outer movements need to be in some sort of balance, of scale and complexity, and that they have precedence over the inner movements (which are often, however, scarcely of any less duration in time, particularly in the case of slow movements). There are two interesting points to this well-worn observation. The first is that writing a Finale is often seen as a 'problem' specific to symphonies, rather than chamber or keyboard works (with the exception perhaps of the late Beethoven piano sonatas). Second, this 'problem' arises out of considerations of the symphonic work as a whole, which require the individual movements not only to be considered as interdependent, but as tracing a progression of thought that bears the characteristics of a narrative. Just as a novel must contain a moment, often readily identifiable as a specific event within the plot, after which the action proceeds towards its conclusion with a sense of inevitability, drawing distinct strands of the earlier narrative together, so the opening of the final movement of a symphony often announces itself in some way as the beginning of a musical narrative that relies for its significance on the movements which have preceded it. Beethoven's Ninth Symphony acknowledges this status of the Finale by introducing fragmentary quotations from the preceding movements before launching into the Ode to Joy; and Mahler has the same portentous sense of the necessity of a 'weighty' conclusion, while proceeding rather differently. The First Symphony Finale begins with a series of musical gestures that make sense only as a method of situating the movement within the larger narrative form of the whole work. In other words, they would be meaningless, within the tonal practice even of the late nineteenth century, as the opening of a tone poem or overture. Peter Franklin attributes much of the negativity in the critical reactions to the Symphony, and even Mahler's decision to provide titles and an outline of a programme to the work in its second and subsequent performances, to the 'assault on polite aesthetic conventions' represented by the opening of this last movement. Mahler's friend from student days in Vienna, Fritz Löhr, reported that the violence of the opening of the Finale caused a lady sitting near him to drop 'all the things she was holding ${ }^{\prime 19}$

Without attempting here a detailed analysis of the passage, some of the semiotic significance of its gestures can be explored. The opening chord is a fortissimo, sustained diminished seventh chord based on $\mathrm{F}$, played on woodwind, horns and trumpets, with $C$ natural in the bass added by lower strings and the two sets of timpani - truly a schrecklicher Klang. The upper strings then enter in bar 3 with the second musical gesture - rushing arpeggio and scalic figures (accelerating through groups of five and six quavers, then four and six semiquavers) establishing an F minor chord. At the same time, the wind and timpani 'resolve' the initial dissonance to an F minor ${ }_{4}^{6}$ triad.

Quite apart from the shock value of this violent passage, which follows the pianissimo dissolution of the end of the slow movement's death march, this initial dissonance, and its resolution to a tonally unstable consonance, cannot fail to connote 'continuation' as the foundation of their signification. In other words, the

19 Franklin, The Life of Mahler: 76. 
Ex. 1 Mahler, First Symphony, mvt. IV, bars 388-391

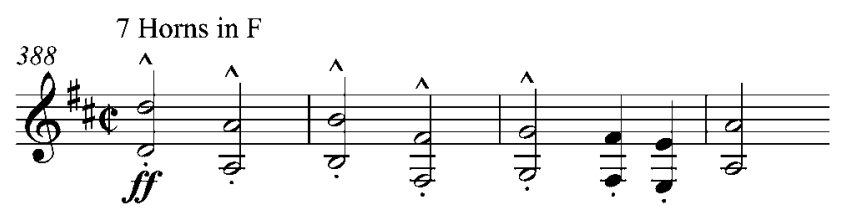

music sounds as if it is the middle of a movement, not the beginning. Simultaneously, the music is quite unlike any of the climaxes or crises of the earlier movements, let alone their orderly beginnings. It is also in a distant key: the earlier movements have hardly strayed beyond their principal keys of $\mathrm{D}$ minor/major and A major. While F minor is not unprepared by the work thus far - the A major Scherzo has a Schubertian excursion to the nearby F major for the first part of its Trio - it nevertheless signals at the outset of the Finale that there is a considerable journey to be made. This journey is to have an ultimately successful conclusion in D major, marked Triumphal by Mahler as it hurtles to its end; but its temporal extension is clear from the start. The signifying force of these bars, then, combines a sense of taking up a discourse in medias res, together with the projection of a lengthy narrative (through the tonal dislocation implied by the key), and the declaration of aesthetic weight and seriousness (implied by the scoring and colossal volume, as well as the harmonic complexity).

The discourse that is being taken up as if previously broken off can only be the narrative discourse of the whole symphony; its connections with the earlier movements, and in particular the first movement, are gradually reinforced by motivic correspondences. There are grounds for describing what emerges eventually as the main theme of the Finale as sharing, and generally inverting, rhythmic cells and intervallic outlines with the main and subsidiary themes of the first movement. These connections are so tenuous, though, as to make them pretty much subliminal. ${ }^{20}$ But the principal point of contact between the two movements, is completely overt: the theme which becomes the main material of the closing triumphal march (see Ex. 1).

This theme is a 'false conclusion', ${ }^{21}$ which is subsequently interrupted, before appearing decisively. It is a major-mode version of the $\mathrm{D}$ minor theme from the introduction to the first movement (Ex. 2).

The conclusion of the symphony thus quite literally takes up the matter with which the entire work began. This opening material, though, has been transformed in character so that it not only proclaims the unity essential to a nineteenth-century extended artwork, but also provides a convincing narrative conclusion, in which the inchoate material which emerges from the Naturlaut of the opening reaches in the Finale a triumphant, affirmatory resolution of the type that Adorno characterised as Erfüllung (fulfilment).

The programme that Mahler provided for this movement, when he felt this necessary for the second performance of the Symphony, is exiguous to say the least. Notably, it accounts only for the opening bars of the movement, linking

20 The idea that the theme of the Finale takes up features of themes from the opening movement, while inverting them or reversing their significatory effect, is, however, clearly observed in later works by Mahler, and it is worth noting here.

21 This is Mahler's phrase. See Franklin, Life of Mahler, 76. 
Ex. 2 Mahler, First Symphony, mvt. I, bars 18-21

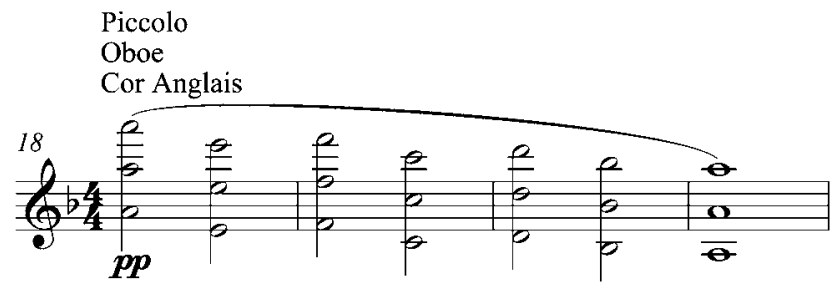

them to the end of the preceding slow movement. One imagines that this was in order to prepare the audience for the shock that had so discomposed Löhr's neighbour at the premiere. Franklin translates as follows:

IV. [...] In this passage the piece is intended to have now an ironically merry, now a mysteriously brooding mood, onto which immediately ...

V. 'D'all Inferno' (Allegro furioso) follows, like the suddenly erupting cry of a heart wounded to its depths. ${ }^{22}$

Mahler's programme seems to cast the overall narrative of the Symphony as an individual's journey, but one through affective states, or 'moods', rather than specific events. Certainly there is no attempt to map the progression traced through the five movements on to Jean Paul's novel; the programme is a different sort of hermeneutic instrument from the analysis which I am presenting here, and, with its passing reference to Dante, it trades in multiple literary references which have allusive, not denotative value. Yet one can still look at the text of Titan to see whether there are resonances with the manner of proceeding chosen by Mahler at the beginning of the Symphony's Finale.

I said earlier that many novels have a specific moment, at which the move towards final resolution of the plot is inaugurated. The twin requirements of returning to topics introduced in the opening section of a novel and constructing an aesthetically satisfying 'closed' ending to the plot, are so common as to be near-universal. In Titan, rather conveniently, one motif that serves a unifying purpose at articulating moments of the narrative's form is that of journeying. The novel opens with a journey across the sea to Isola Bella, where Albano spent the first three years of his life. The Edenic tranquillity of the island, whence Albano has to travel first to Blumenbühl for his education, and then ultimately to Pestitz, is a fitting counterpart to the Naturlaut with which Mahler's Symphony begins. And, while it is difficult to isolate one particular point after which the narrative gains momentum and inevitability until its end, perhaps the best candidate is another journey, this time made by Albano, and significantly placed at the end of the third volume and the beginning of the final fourth volume of the novel. After the death of Liana, and Albano's discovery of his true father's identity, he falls into a delirious fever; he then makes a journey to Rome, before his final (and ultimately triumphant) return to Pestitz. Just as the motivic correspondences in the Symphony serve increasingly to emphasise the importance of the overall narrative structure, so the recurrent motif of travelling binds together articulating

22 Franklin, Life of Mahler, 90. The Symphony had five movements at this time, of course (see n. 7 above). 
moments of the novel's plot. The long journey that opens Volume Four, even ends with a moment of drama similar in tone to the portentous opening of the symphonic Finale:

All at once the Knight ordered the postilion to stop, who passionately threw up his arms toward heaven, while it went on rumbling under the carriage, and exclaimed, 'Holy mother of God, an earthquake!' But Gaspard touched his son, who seemed intoxicated with the splendours of the sunset, and said, pointing, 'Ecco Roma!' ${ }^{23}$

I do not mean by this to suggest that there is a deliberate modelling of the events of the Symphony after those of the novel. The points of connection are remote, and the genuine similarities exist at a very abstract level best described in theoretical terms as structural homologies. Nevertheless, if one were to characterise the sort of musical narrative to which Mahler was clearly drawn in his early symphonies, the best phrase might be 'after the manner of Jean Paul'. The fragmentary points of connection just outlined are symptoms of this affinity. Perhaps the best proof of this is an observation that is also crucial for the overall narrative of this essay, and that is the fact that Mahler's way of constructing symphonic form changes in his later works. While still capable of being described in terms of narrative, the kinds of stories with which the celebrated Director of the Vienna Court Opera engaged were significantly different from those of the ambitious young devotee of Jean Paul climbing the ladder of provincial success.

\section{The disciple of Dostoevsky: narratives of extinction and redemption}

Mahler's love of Dostoevsky, like his interest in Nietzsche, clearly developed at exactly the time that he embarked upon his career as a symphonic composer. It must have been a significant difference between his enthusiasm for Dostoevsky and that for Jean Paul, that he came to the former's works as a near contemporary his favourite novel, The Brothers Karamazov, was published when he was nineteen - whereas from early on, he read Jean Paul with the interpretative lens of the approval of his musical heroes, Schumann and Brahms. The majority of anecdotes concerning his regard for Dostoevsky, such as that with which this essay opened, stem, however, from later in his career. The shift of musical thinking that occurred in Mahler's works after the Fourth Symphony, when it is related to his biography, is usually attributed in some sense to his marriage to Alma, in 1902, and the resulting changes in his circle of friends, and thus intellectual influences. However, it is equally true that musical changes coincided with Mahler's achievement of his lifelong goal of success in Vienna, which came with his appointment as Director of the Court Opera in 1897, and also with the maturing of his artistic (and, indeed, philosophical and ethical) personality, which led increasingly to an identification of his own beliefs with those found in Dostoevsky's works. Of course, it would be as untrue to claim that Mahler lost his affection for Jean Paul, as it would be to deny that he was reading Dostoevsky with fervour while writing the First Symphony. Nevertheless, the narratological outlines of the Fifth, Sixth and Seventh Symphonies differ from those of the first four. The episodic, experimental style, and the overall movement from complexity

${ }^{23}$ Jean Paul, Titan, vol. 2, p. 187 ('Twenty-sixth Jubilee, $102^{\text {nd }}$ Cycle'). 
and confusion to individualistic triumph, which is found in all the early symphonies, while itself being recast and differently worked out in each (particularly in regard to the character of the final movement), is replaced with something at once more individual in some respects, and at the same time more social in its implications.

The most obvious difference in planning concerns the tasks, formally and narratologically speaking, allotted to the Finale. The nexus of concerns discussed above under the label of 'the Finale problem' still remains, but no longer is the Finale the inevitable progress toward ultimate triumph. In terms of narratological parallels, the equivalent of the novel's protagonist - whether interpreted as principal musical material (Schoenberg's elusive Urmotiv), or more abstractly as the 'individual impulse' of subjectivity - is no longer predestined by the requirements of the plot to prevail over all incidental contingencies. This does not mean that the symphony cannot end positively - the Fifth and Seventh both do but it does mean that the conclusion is not presented as foregone, and the Sixth Symphony ends in perhaps the bleakest and most complete catastrophe in the history of the symphony as a form, made all the more terrible by the finelybalanced equivocation between construction and dissolution throughout each movement of the work. Once more, this relates to the 'nominalism' in Mahler's formal thinking which, in Adorno's words, shows 'an aversion to knowing in advance how the music will continue'. ${ }^{24}$ Adorno is not interested in suggesting specific parallels between works of literature and Mahler's procedures - indeed, he warns against it - but the issues he takes up are very much akin to a central concern in Dostoevsky, which is the possibility of redemption of the individual at the conclusion of the novel's narrative. All three of the middle-period symphonies pose this question through the way in which their Finales present themselves; but the answer is different in each case. The work with which Adorno clearly has most sympathy is the Sixth Symphony, undoubtedly partly because its drive towards destruction appeals to his innate pessimism. Just as in the First Symphony, the Finale of the Sixth is linked with the movements that precede it; this is achieved more explicitly in this case through the motivic correspondences between the themes of the first movement and that which opens the Finale. I have made a detailed comparison elsewhere between this work and novels that conclude with the destruction of the central character; ${ }^{25}$ but perhaps of more interest in the present context are the cases of the two symphonies in which Adorno distrusts the final movement.

The breezy optimism of the D major Rondo that closes the Fifth Symphony leads Adorno to an extended comparison of Mahler with Beethoven, taking its starting point from an allusion to the Hammerklavier sonata, which Adorno hears in the opening rondo theme. Adorno's need to maintain that Mahler opposes himself to the acceptance of the bourgeois status quo represented by Beethoven's triumphalism leads him to comment that 'this is only a pro forma main theme; it does not command the movement but is overgrown by others, is in a sense kept outside the door of the interior of the movement' ${ }^{26}$ Adorno's observation is, as ever, well founded, in that the main theme of the final movement is not the material which is used to produce the celebratory climax of the work; but his

24 Adorno, Mahler, 62.

25 Samuels, Mahler's Sixth Symphony; the novels discussed are, principally, Anna Karenina and Madame Bovary.

26 Adorno, Mahler, 63. 
difficulty with Mahler's positive mood, at times when it is hard to claim that it underpinned by irony, leads him to ignore the justification of this movement (and indeed its opening theme) through its position as the closing gesture of a symphonic narrative which is now after the manner of Dostoevsky rather than Jean Paul - oriented towards redemption of the individual impulse rather than the inevitability of its triumph.

There are two respects in which this reading of Mahler's handling of form goes beyond mere description of mood, towards something more properly narratological. First is the willingness on Mahler's part to accept that a narrative can end in more than one way. The form of an entire symphony needs a coherent overall shape, but the contours of this, and specifically the nature of its conclusion, are not predetermined. This is the fundamental nature of Adorno's 'aversion to knowing in advance how the music will continue'. However, Adorno's unwillingness to be convinced by the conclusions of either the Fifth or the Seventh Symphonies seems to miss the point that he himself is making: Mahler starts each of the three symphonies in darkness, uncertainty, even despair; but he concludes the symphonic narrative in three different ways. The possibility of eucatastrophe - what I am terming here redemption - may prove to be unfulfilled, but it must nevertheless still exist as a genuine possibility. The Fifth Symphony is the one that gives the most optimistic conclusion, and the second respect in which my reading is narratological is the claim that the term 'redemption' is justified, rather than something more neutral such as 'positivity' or something more prosaic such as 'balancing major key movement'.

To give the briefest of analyses of the semiotic content of 'redemption' as a term, the idea seems to involve several characteristics simultaneously: a sense of history, or extension through time; an originating, negative state; a final, positive state; connectedness between these states, so that the last is a transformation of the first, but one which affirms the fact that its potential always existed; and lastly, this transformation is often (though not always) attributable to an outside agency. In Crime and Punishment, Raskolnikov is redeemed as much from his tendency towards corrupt, Western rationalism and sophistry as from his crimes; indeed, the latter are in essence the murderous outgrowth of the former. And his redemption is effected through his sister Sonya, as much because she is representative of pure Russian spirit, as through her Christian piety; and once again, these two are not distinguishable in the moral and political universe of the novel. Redemption, then, is a label for a whole nexus of complex issues which are invoked and resolved by the narrative.

In musical terms, these simultaneous signifying structures can be identified in the manner in which Mahler creates the transition to the final movement of the Fifth Symphony. As in the First Symphony - and indeed it is a persistent formal habit of Mahler's - the movement has an extended introduction with a different tonal centre from that which is eventually established as the main key of the Finale. Here, however, this extended introduction takes the form of an entire movement: the Adagietto. The key of the Finale is the outcome of a tonal process that extends over the entire symphony. In the case of the Fifth Symphony, this goal is D major, and during the symphony it is approached first via the C sharp minor and A minor that are the keys of the first two movements (the 'first part' in Mahler's description); it is established in the Scherzo (the longest movement of the symphony), and then approached again from the F major of the Adagietto to close the work. The 'originating negative state', therefore, is represented by three linked keys, each a major third from the others: C sharp, A, F; the destiny of 
which is to resolve to D major. The sense of 'progressive tonality', where a piece travels through keys in a meaningful sequence, ending in a different place from where it began, is stronger in this symphony than in any other of Mahler's works. Here it is harnessed to a symphonic narrative of transformation, which I am describing as redemption. If it is fair at all to describe this piece as 'in' a single key, then that key ought really to be the D major of the Scherzo and Finale, not (as the title page and recordings would have it), the $C$ sharp minor of its opening. If this long-range tonal scheme is the backdrop to the symphonic narrative, then the process of transformation is worked out at a local level by the network of motivic resemblances and cross-references which link movements together. The transformation of original state to final state is completed by the opening bars of the Finale. The A natural with which the first violins close the Adagietto is picked up an octave higher by the horn, as the pitch that connects the tonic chords of the two movements (F major and D major). In sum, the semiotic profile of musical gesture in Part III of the symphony seems to me to exhibit the features of 'redemption' as an organising abstract concept. The original, negative state of Part I is transformed in the Finale, with the Adagietto which constitutes its extended introduction acting as, or at least symbolising, the 'external' agency effecting this change.

This miniature piece of analysis can serve no more than to suggest the outlines of the musical narrative created through the complex, dense play of tonal and motivic transformations which sustain the richness of this work. Adorno's instinct seems sound, that narrative is the best analogue for the formal construction of the symphony; however, Adorno's distrust of this particular work also appears unfair, and indicative of an unwillingness to accept a symphonic narrative that aims towards an ultimately positive conclusion, at least in the Dostoevskian sense of a redemption won possibly at great cost or with bitter regrets.

One thing that is evident from the Fifth, Sixth and Seventh Symphonies is Mahler's willingness to experiment, in these works, with different possible versions of symphonic form, which is to say with different possible symphonic narratives. This is the necessary correlative of Adorno's 'aversion to knowing in advance how the music will continue'; the different works confirm that different outcomes are genuinely possible within the Mahlerian musical world view. If the Fifth Symphony presents redemption and the Sixth extinction, as the culmination to the narrative, it is perhaps not surprising that Mahler followed them with a symphony whose narrative outlines have been perpetually perplexing for critics, since its Finale presents a finely-balanced equivocation between these alternative destinies for its material. Perhaps the best discussion of the ambivalent contours of the Finale of the Seventh Symphony is John Williamson's discussion of cadences. ${ }^{27}$ Williamson is concerned to relate analysis of compositional technique to the issues raised by previous criticism; he characterises the opposing camps of critical interpreters of the work as fundamentally the Adornian and antiAdornian viewpoints. The technical feature on which he focuses is Mahler's repeated use of 'interrupted' or 'deceptive' cadences, beginning with the abrupt swerve from $\mathrm{C}$ major into A flat at the conclusion of the opening theme of the Finale. There is no point in reproducing here the detail of Williamson's discussion, which quite brilliantly unites abstract interpretation with objectively-founded

27 John Williamson, 'Deceptive Cadences in the Last Movement of Mahler's Seventh Symphony', Soundings 9 (1982): 87-96. 
analysis; but the thrust of his article is to locate a moment of undecidability within the narratological organisation of the symphony as a whole. The deceptive cadence, which is a standard technical means in tonal harmony for signalling an unexpected continuation of a theme, acquires through repetition an insistence that requires interpretation. On the one hand it is familiar, and so apparently transparent in harmonic meaning; this 'legibility' of tonal function accords with the optimistic, major-key dominated rondo form. But on the other hand this legible meaning, since its function is to interrupt the linearity of the tonal progress, is precisely what is at odds with the major-key optimism. For the Adornian camp of interpreters, this paradox becomes 'the crack sought by the metacritics in the mirror of positivity'. Williamson sums up, using a phrase from Jonathan Culler, by concluding that the deceptive cadence 'offers itself, as a "teleologically defined function", as a major structuring force in a hermeneutical enigma'.28

It was remarked earlier that Mahler came to Dostoevsky as a near contemporary, an observation that admittedly stretches the point somewhat, in that Dostoevsky died when Mahler was still in his twenties. In his 'late style', however, Mahler can be seen to be addressing issues which certainly also preoccupied writers more genuinely his contemporaries. Adorno, as a pupil of Berg, was particularly concerned to claim that at the end of his life, Mahler was foreshadowing the New Music; in other words, that he was part of the evolving movement across the arts which we now label as Modernism.

\section{The contemporary of Musil and Proust: the Ninth Symphony}

Although many of the artworks that come to mind immediately as examples of the Modernist movement tend towards extreme concision - one thinks of Schoenberg's Piano Pieces Op. 11, or the nearly 'plotless' short stories of Katherine Mansfield - there is, equally, a tendency in another strand of the movement towards more and more extreme length. Webern's sense of the limitations of the elements of tradition, so that once each of the twelve semitones has been stated, any further extension to a piece of music risks redundancy or tautology, is matched by James Joyce's sense of the need for endless re-writing of the subject, at successively greater length and greater risk of incomprehensibility, represented by the parallels and disjunctions between Portrait of the Artist as a Young Man (itself a coalescence out of elements of the unfinished Stephen Hero) and Ulysses (many might add Finnegans Wake as a third term of this unclosed series). One might perhaps contrast these alternative reactions to the problematics of expression as 'modernist concision' and 'modernist extension'.

In this context, the 'late style' of Mahler begins to appear as a more fundamental shift of focus compared with the works of 1900-07. While the Ninth and Tenth Symphonies are of no greater length than several of the earlier works, they display exactly the constellation of contradictory aesthetic impulses of this 'modernist extension'. To continue this essay's exploration of points of contact between Mahler's music and literary analogues, I would like to place Mahler's late style, specifically as represented by the Ninth Symphony, alongside two enormous novels which may serve as examples of literary Modernism: Robert Musil's

28 Williamson, 'Deceptive Cadences', 96. 
Der Mann ohne Eigenschaften (The Man without Qualities) and Marcel Proust's À la recherche du temps perdu (In Search of Lost Time). At this point, the attempt to consider together even one symphony of the complexity of the Ninth, and two novels which have a combined length in excess of 5000 pages, risks appearing laughable, quite apart from impossible. However, with the reiteration, even more firmly than before, that what is proposed is not a translation of one artwork into another, or the contention that these projects share subject matter beyond the most abstract of categorisations, it is rewarding to search out some of the resemblances and contrasts between them at the level of their constellations of structural concerns. This may succeed not only in illuminating aspects of these chosen artworks, but also in contributing to the history of aesthetic ideas that aspires to describe such a wide variety of artistic products within the same category as each other.

One of my initial contentions regarding Musil and Proust is that they can be regarded as in some sense closing a history, which is that of 'the novel'; or, at least, the realist novel of the nineteenth century. Of course, carving out any aesthetic history of this sort is open to contention, and its necessary arbitrariness will always limit its potential usefulness; but it has at least pragmatism to recommend it, and perhaps more.

These novels share a theme which in a sense is that of all Modernism: the status of the individual subject. In each case, this is an exploration of whether and how one can come to knowledge of the essential rather than the accidental in human nature; but it is conducted within a narrative that frames these questions in ways inextricable from the historical and social moment which provides each novel's setting. It is also true that, if one can draw this point of similarity between the concerns of Musil and Proust, they come to quite different conclusions within novels of radically different profiles.

Musil's novel is set in the year 1913, and the fact that so little time passes in the course of its great length is a symptom of its subject matter. Its central character Ulrich takes a 'year out' from his career, intending at its end either to readopt the 'qualities' necessary to participate in society, or to commit suicide. The stagnation of Ulrich's life, his inability to find a rational basis for action of any sort, is not only reflected in, but is a direct outcome of the state of the Austro-Hungarian Empire which is the backdrop to the book. A sense of the identification of the protagonist, his social moment and the geography of Vienna can be gauged from a moment of self-reflection late in the novel, which occurs within Ulrich during an evening walk around the Ringstrasse:

Anyone who has had the experience of seeing some earlier incarnation of himself gazing at him from an old photograph, wrapped in a bygone moment of selfsatisfaction, as if glue had dried up or fallen out, will understand Ulrich's asking himself what sort of glue it was that seemed to hold for other people. He had now reached one of those green spaces bordered by trees, a break in the Ringstrasse, which follows the line of the ancient city walls, and he might have crossed it in a few strides, but the broad strip of sky above the trees made him turn aside and follow where it was leading, seeming to come closer and closer to the festoons of lights so intent upon their privacy in the distant sky above that wintry park, without actually getting any nearer to them. ${ }^{29}$

29 Robert Musil, The Man Without Qualities, trans. Sophie Wilkins and Burton Pike (London: Picador, 1995), vol. 2 (Chapter 122): 707. 
This leads to a self-referential passage which is almost a manifesto of the impossibility of writing the book currently being read:

Most people relate to themselves as storytellers. They usually have no use for poems, and although the occasional 'because' or 'in order that' gets knotted into the thread of life, they generally detest any brooding that goes beyond that; they love the orderly sequence of facts because it has the look of necessity. and the impression that their life has a 'course' is somehow their refuge from chaos. It now came to Ulrich that he had lost this elementary, narrative mode of thought to which private life still clings, even though everything in public life has already ceased to be narrative and no longer follows a thread, but instead spreads out as an infinitely interwoven surface. ${ }^{30}$

One of the most significant aspects of these extracts is the role they give to memory in the construction of the self. It is this which justifies using this brief passage to emblematise perhaps the main theme of Musil's entire work; and it is also a point of contact between Musil's modernism and Proust's. Musil's protagonist is literally caught between the urban society symbolised by the Ringstrasse, and the integrated life towards which he aspires, symbolised by the stars 'so intent upon their privacy in the distant sky above'. He questions whether imposing a 'realist' narrative on the contingencies of his past life is justifiable. This is why his memory of his past self is alien, frozen 'as if glue had dried up or fallen out'. The modernist's fascination with questions of self, identity, essence and the like, coupled with a distrust of the assumption of 'realist' narrative to tame the unruly facts of existence, is shared by Proust; however, the protagonist of $\grave{A}$ la recherche $d u$ temps perdu comes to quite different conclusions, because his relationship with memory and the perception of the pastness of the past is quite different from Ulrich's. Proust's protagonist reaches a crisis of identity in some ways similar to that of Musil's Ulrich quoted above, at the end of the first volume of the novel (Du côté de chez Swann), when he returns to Paris expecting it to have the magical qualities he remembers from his childhood:

The reality which I had known no longer existed. It was enough that Madame Swann did not arrive in just the same way and at the same time, for the Avenue to be quite other. The places which we have known do not belong simply to the world of space where we place them for our convenience. They are only a small slice in the midst of contiguous impressions which make up our life of that time; the memory of a particular image is no more than the regret for a particular moment; and houses, roads, avenues slip away, alas! as do the years. ${ }^{31}$

Both Proust and Musil use the discontinuity between the remembered past and the lived present as a point of entry to understanding the human self. This is also the point of contact with the Mahler of the Ninth Symphony. Throughout Mahler's oeuvre, there is an often-remarked technique of self-quotation, quotation of other composers, and use of material which evokes or is reminiscent of other music (especially other Mahler) without actual direct quotation. ${ }^{32}$

30 ibid, 709.

31 Marcel Proust, In Search of Lost Time 1: The Way by Swann's, trans. Lydia Davis (London: Penguin, 2002 [1913]): 430.

32 This topic is explored in my essay 'Mahler within Mahler: Self-reference or Metareference?', in Self-reference in Literature and Music, ed., Walter Bernhart and Werner Wolf (Amsterdam: Rodopi, 2010): 33-50. 
Ex. 3 Mahler. Ninth Symphony, mvt. IV, bars 148-163
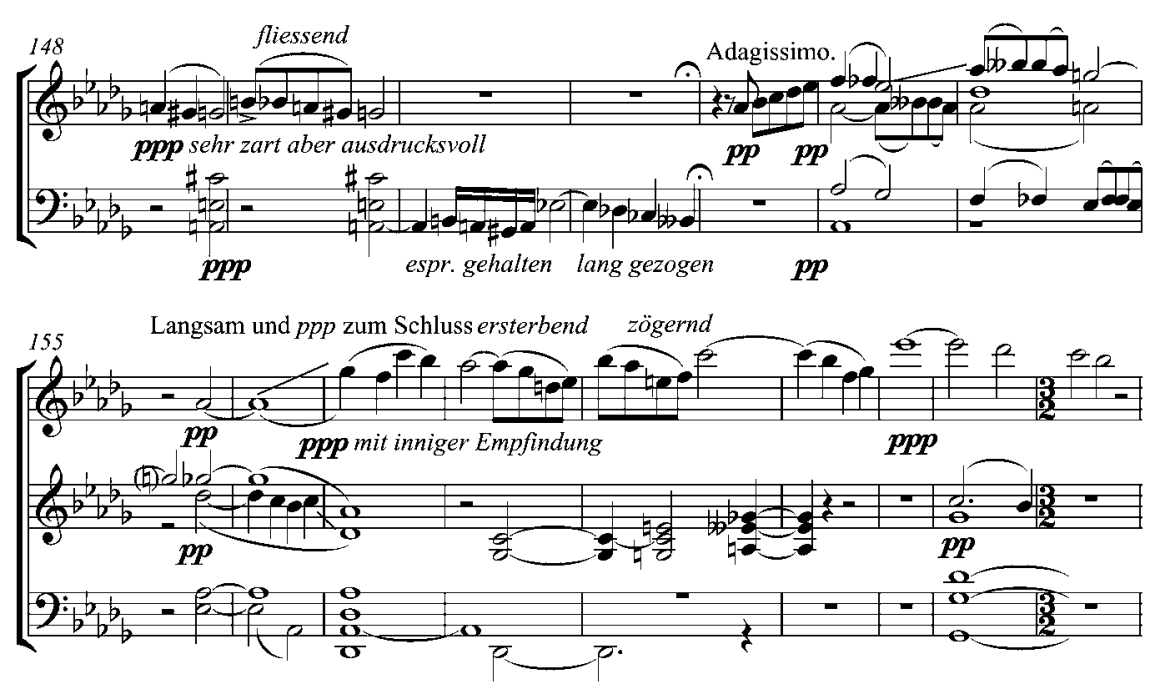

Often, this amounts to a representation of memory within the symphonic narrative; it reaches a higher level of intensity in the last movement of the Ninth Symphony than ever before. Adorno is particularly sensitive to this aspect of Mahler's works, and it is fundamental to his extensive comparisons of Mahler's symphonic writing and novelistic technique. He comments generally of Mahler:

Where he repeats past material for formal reasons, he does not sing its praises or those of transience itself. Through the variant his music remembers things past and half-forgotten from a great distance, protests against their absolute fruitlessness and yet pronounces the past ephemaral, irrecoverable. ${ }^{33}$

The last pages of the Ninth Symphony are entirely composed from fragments of melody which seem not only to recall earlier moments of this movement, but earlier works by Mahler too. Example 3 shows this in bars 148-163, which are followed by the composing-out of the final D flat triad.

From bar 155, the first violin (the top stave in Ex. 3) quotes the melody of one of the Kindertotenlieder. Most of the other short phrases in the extract are examples of Mahler's 'idiolect', familiar from many earlier works, and their effect here, combined with the extreme fragmentation of the music, is to produce the sense of present experience entirely composed out of memories of past events.

The conclusion of this, Mahler's last completed symphony, is worth comparing with the conclusions of both Proust's and Musil's novels. Both novels are, famously, unfinished; each author worked at his enormous manuscript in ill health, and each was ultimately to be prevented by death from its completion. There is a sense in both cases, though, that the novel is not just unfinished, but unfinishable. Musil left a quantity of posthumous papers amounting to half the length of his published novel, and working over multiple possible endings, revolving around differing possible developments of Ulrich's relations with the

33 Adorno, Mahler, 94. 
central female characters of the novel. Proust's novel thematizes its own unfinished state, as the last sentence of the final volume expresses anxiety that the protagonist may not have time to complete the book which the reader has ostensibly now read:

Therefore, if enough time was left to me to complete my work, my first concern would be to describe the people in it, even at the risk of making them seem colossal and unnatural creatures, as occupying a place far larger than the very limited one reserved for them in space, a place in fact almost infinitely extended, since they are in simultaneous contact, like giants immersed in the years, with such distant periods of their lives, between which so many days have taken up their place in Time. ${ }^{34}$

While Mahler's Ninth Symphony is a finished work in the ordinary sense and Proust's and Musil's novels are not, the unfinished quality of the gestures in its final pages betray an anxiety concerning the validity of the novelistic symphonic narrative whose nineteenth-century history Mahler did so much to extend. In this, Mahler moves beyond his early infatuation with Jean Paul and mature admiration for Dostoevsky, to become a founder of twentieth-century Modernism.

34 Proust, In Search of Lost Time 6: Finding Time Again, trans. Ian Patterson (London: Penguin, 2002 [1927]): 358. 